\title{
ОСОБЛИВОСТІ ВИКЛАДАННЯ ВИЩОЇ МАТЕМАТИКИ АНГЛІЙСЬКОЮ МОВОЮ СТУДЕНТАМ КОМП'ЮТЕРНИХ СПЕЦІАЛЬНОСТЕЙ
}

\author{
Антоніна Рибалко \\ кандидат фізико-математичних наук, доцент \\ доцент кафедри вищої математики та економіко-математичних методів, \\ Харківський національний економічний університет імені Семена Кузнеця, \\ м. Харків, Україна \\ ORCID ID 0000-0002-2253-1393 \\ antonina.rybalko@hneu.net

\section{Катерина Стспанова} \\ кандидат фізико-математичних наук, доцент \\ доцент кафедри вищої математики та економіко-математичних методів, \\ Харківський національний економічний університет імені Семена Кузнеця, \\ м. Харків, Україна \\ ORCID ID 0000-0003-2294-155X \\ stepanova.ekaterina@hneu.net
}

\begin{abstract}
Анотація. Статтю присвячено актуальній проблемі викладання вищої математики англійською мовою в мультинаціональних групах студентів комп'ютерних спеціальностей. Отримання англомовної професійної освіти все більше приваблює сучасну молодь перспективами участі в програмах академічної мобільності та продовження навчання в провідних університетах світу, підвищення їхньої конкурентоздатності на ринку праці. Проаналізовано поширені проблеми мовного та предметного характеру, що виникають в процесі навчання українських та іноземних студентів, що не $є$ носіями англійської мови. Надано рекомендації щодо організації занять i підготовки методичних матеріалів, запропоновано засоби діагностики. Приділено увагу особливостям математичної підготовки майбутніх фахівців сфери інформаційних технологій. Наведені підходи, за досвідом авторів, дозволяють підвищити інтенсивність пізнавальної діяльності студентів загалом і покращити якість отриманих знань і навичок.
\end{abstract}

Ключові слова: вища освіта; вища математика; викладання англійською мовою; мультинаціональні групи; студенти комп'ютерних спеціальностей.

Постановка проблеми. Актуальною тенденцією сучасної національної освіти є невпинне зростання контингенту, що навчається іноземною мовою. У Харківському національному економічному університеті ім. С. Кузнеця такі студенти поділяються на дві категорії: це іноземці, що отримують вищу освіту в Україні, та українські студенти, що виявили бажання навчатися англійською мовою. I хоча, звичайно, є особливі навчальні потреби в кожної з цих категорій, спільним $є$ те, що для всіх англійська мова не $є$ рідною. До того ж математика $\epsilon$

Професіоналізм педагога: теоретичні й методичні аспекти. - Вип. 12. - Слов’янськ, 2020. 
складною дисципліною сама по собі, тобто природні проблеми оволодіння матеріалом множаться на мовні труднощі сприйняття. Тому викладання вищої математики іноземною мовою потребує грунтовного науково-методичного супроводження, що відповідає особливостям та характерним проблемам такого навчання.

Аналіз останніх досліджень і публікацій. Досліджувана проблема є багатогранною. Її складовими є різні питання навчання іноземних студентів, аспекти викладання фундаментальних дисциплін англійською мовою, особливості роботи в багатонаціональних групах студентів.

До вивчення психолого-педагогічних проблем адаптації та навчання іноземних студентів звертались у своїх роботах такі вітчизняні та зарубіжні вчені, як Г. Алєєва, О. Білоус, Н. Булгакова, О. Добротвор, Т. Довгодько, М. Іванова, О. Суригін, І. Сладких, О. Палка, I. Семененко, Т. Каткова, Т. Кочарова та інші.

Питання навчання математики на підготовчих факультетах закладів вищої освіти розглядалися, зокрема, С. Вятчаніною, О. Віхровою, Н. Зінонос, О. Громовим, О. Хачатуровою, І. Міловановою, Ю. Максименко. Різним аспектам викладання математичних дисциплін іноземним студентам у вишах присвячено роботи І. Мілованової, В. Петрук, В. Лєсового, Н. Дубової, І. Клєопа, О. Сачкової, Т. Грицик та інших.

Проблеми викладання фундаментальних i спеціальних дисциплін англійською мовою в закладах вищої освіти різних профілів вивчали О. Джеджула, В. Пришляк, Т. Хом’яківська, С. Федак, Л. Романюк, К. Власенко (2018), І. Степанян, Г. Дубиніна, О. Ганіна (2017) та інші науковці. Специфіку організації навчання в мультинаціональних групах майбутніх фахівців авіаційної галузі досліджено в серії статей О. Карупу, Т. Олешко, В. Пахненко $(2011 ; 2012 ; 2018)$. При цьому особливості англомовного навчання вищої математики студентів галузі інформаційних технологій залишаються недостатньо висвітленими.

Формулювання цілей статті. Метою статті $\epsilon$ обговорення загальних проблем викладання вищої математики іноземною мовою в закладах вищої освіти; обгрунтування доцільності та ефективності впровадження англомовної математичної підготовки в сучасних умовах; дослідження особливостей викладання математичних дисциплін студентам комп'ютерних спеціальностей; представлення власного досвіду викладання та створення методичного супроводження курсу і наведення пропозицій щодо активізації та покращення результатів пізнавальної діяльності майбутніх ІТ-фахівців. 
Результати дослідження. Причинами поширення англомовного навчання в України останнім часом $є$ насамперед інтенсифікація інтеграційних процесів у світовий освітній та науковий простір. По-перше, завдяки цьому ми спостерігаємо збільшення іноземного контингенту в закладах вищої освіти майже всіх профілів. 3 іншого боку, розвиток академічної мобільності значно збільшує інтерес до навчання іноземною мовою серед вітчизняних студентів.

У ХНЕУ ім. С. Кузнеця впроваджено навчання англійською мовою з усіх програмних предметів. Викладання математичних дисциплін студентам різних спеціальностей забезпечує кафедра вищої математики та економікоматематичних методів. Ми розглянемо особливості математичної підготовки студентів комп'ютерних спеціальностей іноземною мовою.

Навчання англійською мовою 3 погляду сучасної молоді має численні переваги, особливо для майбутніх фахівців галузі інформаційних технологій. Незважаючи на безсумнівні додаткові труднощі, усе більше студентів усвідомлено обирають цей шлях. Отримання англомовної освіти розкриває перед студентами комп'ютерних спеціальностей такі перспективи:

- можливість поглибити знання англійської мови, збагатити свій лексичний запас предметною та професійною термінологією, розвинути навички спілкування, ведення дискусії;

- можливість проходити стажування або продовжувати навчання за кордоном, брати участь у програмах подвійних дипломів, у міжнародних проєктах у галузі комп'ютерних наук тощо;

- здатність бути конкурентоспроможним на міжнародному рівні та отримати можливість працювати в провідних IT-компаніях світу;

- суттєве розширення можливостей для побудови індивідуальної траєкторії навчання;

- здатність до самоосвіти, особистісного росту та неперервного підвищення професійної кваліфікації впродовж життя, що $\epsilon$ необхідною компетентністю будь-якого сучасного IT-спеціаліста тощо.

Щоб справдити очікування студентів від опанування дисциплін англійською мовою, викладачі повинні відповідально і ретельно підготуватися до навчального процесу. Необхідно визначитися з форматом і організаційними аспектами занять, розробити якісне і різноманітне методичне супроводження курсу, приділити увагу іншим дидактичним питанням.

У ХНЕУ ім. С. Кузнеця, як і в багатьох інших вишах, англомовне навчання переважно відбувається в мультинаціональних групах. Природно, що склад таких груп є вельми неоднорідним як за рівнем знань англійської мови, так і 3

Професіоналізм педагога: теоретичні й методичні аспекти. - Вип. 12. - Слов’янськ, 2020. 


\section{А. РИБАЛКО, К. СТЄПАНОВА \\ Особливості викладання вищої математики англійською мовою студентам комп'ютерних спеціальностей}

погляду математичної підготовки. Висвітлимо основні проблеми загального характеру, що спостерігаються на практиці.

У реаліях сьогодення англійська мова не є рідною як для українських, так i для іноземних студентів нашого університету. Тому всі без винятку учасники навчального процесу стикаються із значними труднощами на шляху переходу до навчання англійською мовою. Навіть студенти, у яких загальний рівень англійської є достатньо високим, зазвичай недостатньо володіють математичною термінологією і не мають навичок обговорювання питань математичного характеру. До того ж кожен випускник українського вишу має опанувати й українську спеціальну термінологією. Це питання не $є$ лише формальною вимогою, бо більшість вітчизняних і певний відсоток іноземних студентів згодом працюють в Україні. Так, навчання фактично перетворюється на білінгвальне.

Що стосується математичної підготовки, тут ситуація ще складніша. Навіть вітчизняні студенти мають різний багаж знань залежно від закладу, що вони закінчували. Зміст шкільних програм в інших країнах має ще більші відмінності. До того ж слід зважати на те, що в одній аудиторії опиняються люди, які навчалися в різних системах освіти, де традиції і методологія викладання інколи значно відрізняється від загальноприйнятих у нашій країні.

Так студенти, що вивчають вищу математику англійською мовою, зазнають подвійного навантаження: $з$ огляду на мовний бар'єр, з одного боку, i через об'єктивну складність предмета - 3 іншого.

Нарешті, зауважимо, що можливі також ускладнення через відмінності менталітету і культур студентів у мультинаціональних групах. Представники різних етнічних і релігійних спільнот мають певні специфічні психологічні особливості. У випадку виникнення комунікативних проблем між студентами під час занять викладачеві необхідно виступати модератором, щоб уникнути серйозних конфліктних ситуацій.

3 огляду на викладене вище, ми вважаємо, що кожен викладач задіяний у навчальному процесі англійською мовою, повинен ставити перед собою такі задачі:

- створити умови для адаптації студентів до умов нового мовного та соціального середовища;

- підготувати матеріали та розробити схему для компенсування недоліків шкільної підготовки паралельно з опануванням програми вищої математики;

- навчити англомовної математичної термінології та можливостям іiї використання під час обговорення математичних питань та письмового викладу матеріалу, запису розв’язків задач тощо; 
- забезпечити інтенсивне спілкування між учасниками начального процесу, розвинути навички англомовної комунікації студентів;

- надати якісну теоретичну математичну підготовку та забезпечити опанування практичними навичками побудови математичних моделей, розв’язання задач практичного характеру, застосування математичного апарату для проведення розрахунків тощо;

- закласти фундаментальні основи для подальшого навчання спеціальних дисциплін і наукових досліджень.

Підготовка до викладання будь-якого курсу починається 3 розробки методичного забезпечення. У випадку викладання іноземною мовою виникає потреба в значно більшій кількості різнопланових матеріалів.

Передусім необхідно створити якісні англомовні конспекти лекцій, практичних і лабораторних занять, розробити завдання та методичні вказівки для самостійної роботи, засоби для діагностики та самодіагностики. Крім цих звичайних матеріалів, корисними супроводжуючими матеріалами будуть словники математичних термінів і стійких виразів, а також відомості зі шкільного курсу математики. Найзручніше їх зробити відразу відповідно до кожної теми, що вивчається.

За довгі роки викладання англійською мовою викладачами кафедри вищої математики та економіко-математичних методів ХНЕУ ім. С. Кузнеця було опубліковано серію робіт (Panova, Titarev, Toreanik, 1995; Misiura, Stiepanova, 2017) із методичного забезпечення дисципліни, і щороку банк матеріалів поповнюється.

У контексті підготовки конспектів лекцій, на погляд авторів, важливим є питання принципів його створення. Багато викладачів обмежується перекладом наявних україномовних або російськомовних підручників із вищої математики англійською мовою. Але традиції викладу матеріалу інколи помітно відрізняються в західній та національній математичних школах, а формальний переклад не співпадає з термінологією, що використовується за кордоном. Оскільки однією із цілей англомовного навчання $є$ надання можливості студентам продовжувати навчання за кордоном, необхідно забезпечити їх знаннями різних підходів.

Водночас вдаватися до іншої крайності i сліпо копіювати західні підручники, на наш погляд, також небажано. Вітчизняна система математичної освіти користується повагою в усьому світі, тому наш обов'язок ознайомити студентів з іiі напрацюваннями, щоб вони отримали всі вигоди від навчання в нашій країні. Так, ми вважаємо за потрібне дотримуватись компромісу між 


\section{А. РИБАЛКО, К. СТЄПАНОВА \\ Особливості викладання вищої математики англійською мовою студентам комп'ютерних спеціальностей}

західними та українськими традиціями викладання вищої математики. Різні погляди поглиблюють розуміння предмета, збагачують арсенал можливостей студентів і врешті-решт підвищують якість освіти.

Перейдемо до обговорення практичних питань організації начального процесу. Автори переконані, що під час упровадження навчання англійською мовою слід зважати на особливості аудиторії та обставин, що визначались вище, тому кожна форма пізнавальної діяльності має бути переосмисленою й адаптованою.

Розглянемо окремо кожний вид занять і наведемо наше бачення основних проблем і можливих шляхів їхнього подолання.

Лекції визначають змістове наповнення курсу i $€$ основою всієї пізнавальної діяльності студентів.

В умовах англомовного навчання доцільно розпочинати лекцію із знайомства 3 термінологією за темою. Для цього можна порекомендувати створити два види словничків. Перший повинен складатися 3 термінів англійською й українською мовами, що належать до тематики (як нових, так $\mathrm{i}$ вже відомих). Звичайно, студенти можуть користуватися готовими англоукраїнськими словниками (наприклад, Нікулін, Наконечна, 2013), але краще лектору створити такий словничок самому з огляду на план заняття. У другому англомовному тлумачному словничку за темою ми пропонуємо навести: термін, його математичне позначення i, нарешті, його тлумачення (означення). Нерідко трапляється, що деяке поняття має кілька синонімічних назв і навіть кілька способів позначення. У цьому випадку бажано навести якомога більше еквівалентів водночас. Деякі терміни є складовими стійких математичних виразів, у цьому випадку їх також доречно навести.

Ще одним супроводжуючим матеріалом повинні бути відомості зі шкільного курсу математики, що зустрічаються та використовуються під час вивчення цієї теми. У них необхідно нагадати основні поняття, обов'язково навести всі формули, а інколи навіть найпростіші приклади їхнього використання. Досвід показує, що, наприклад, формули тригонометрії або похідні основних елементарних функцій майже ніхто із студентів не може пригадати самостійно.

Краще за все забезпечити студентів супроводжуючими матеріалами заздалегідь. Для цього їх необхідно розмістити на сторінці відповідного електронного курсу або видати в роздрукованому вигляді на попередньому занятті.

() ДВНЗ «Донбаський державний педагогічний університет» 


\section{А. РИБАЛКО, К. СТЄПАНОВА \\ Особливості викладання вищої математики англійською мовою студентам комп'ютерних спеціальностей}

Переходячи до обговорення викладення основного програмного матеріалу, зазначимо, що в наш час викладачі математики поділяються на прихильників традиційної форми лекції та тих, хто використовує мультимедійні засоби. Звісно, специфіка предмета полягає в чіткій логічній послідовності, тому поява формули на дошці 3-під рук викладача в деякому сенсі сприймається краще. Але в контексті навчання іноземною мовою автори вважають за доцільне використовувати презентації під час лекції. $€$ кілька важливих аргументів на користь такого підходу. Найголовніше - це знімає частину навантаження 3 викладача, що дає змогу підтримувати неперервний зоровий контакт 3 аудиторією. Як наслідок, у лектора $є$ можливість контролювати стан сприйняття матеріалу, у разі потреби зупинитися на якомусь моменті більш грунтовно, розпочати обговорення якогось питання тощо. До того ж інформатизація всіх сфер життя на сьогодні досягла такого рівня, що нове покоління не так вже i налаштоване на рукописні тексти, тим більше, що в багатонаціональних групах часто витрачається час на «розшифрування».

Під час лекції необхідно зважати на те, що студенти виконують подвійну роботу: перекладають на рідну мову та намагаються розібратися в зовсім непростому насправді матеріалі. Тому передусім слід звернути увагу на темп викладання, пояснення повинні бути повільними і виразними. Крім того, слід розробити засоби для пожвавлення лекційного заняття і полегшення сприйняття великого об’єму нової інформації. Для цього слід час від часу переключати увагу студентів на інший вид діяльності. Наприклад, запропонувати розв'язати самостійно нескладний приклад із подальшим обговоренням отриманого результату. За можливості добре продемонструвати відеоролик або симуляцію за темою заняття, навести приклад розв'язання задачі системою комп'ютерної математики тощо.

На відміну від лекцій для практичних занять (знову ж таки в традиціях вітчизняної системи освіти) характерним $є$ інтенсивне спілкування всіх учасників навчального процесу. Поширеною проблемою $є$ неоднаковий рівень комунікативної компетентності студентів. По-перше, не всі здатні вільно підтримувати бесіду, по-друге, зазвичай відсутні навички спілкування за тематикою дисципліни.

Математика - це своєрідна інтернаціональна мова, якою формули чи математичні висловлювання записують однаково в усіх куточках світу. Тому під час читання, скажімо, підручників іноземною мовою більшість людей намагається лише зрозуміти математичні вирази, а не сформулювати, тобто фактично сприймають їх рідною мовою. Але під час спілкування виникає

Професіоналізм педагога: теоретичні й методичні аспекти. - Вип. 12. - Слов’янськ, 2020. 
потреба у вимові цих формул, і виявляється, що багатьом бракує відповідної лексики. Тому деякий час практичного заняття доведеться присвятити вдосконаленню знання англійської мови.

Розпочинати практичні заняття, на наш погляд, слід із вправ з оволодіння термінологією. Передусім слід провести детальне обговорення нових понять. Потім слід виконати вправи кількох типів. Спочатку запропонувати прочитати вголос математичні викладки, що складаються лише з формул і кванторів. Потім записати ці формули словами. Нарешті виконати вправи на запис невеличкого математичного тексту за темою під диктування.

Основна частина заняття, безумовно, присвячується розв’язанню задач за темою. Для того щоб підвищити зацікавленість аудиторії, ми рекомендуємо починати 3 прикладів застосування апарату, що вивчається в майбутній професійній діяльності студентів. Добре сприймаються також паралелі між аналітичними та чисельними методами вирішення практичних завдань.

Під час розв'язання практичних завдань слід стимулювати студентів ставити запитання викладачу та одне одному, наполягати на поясненні та обгрунтуванні своїх рішень. Бажано також розробити завдання, що передбачають розгорнутий аналіз та міркування вголос.

Окремим видом робіт є вирішення практичних завдань із застосуванням комп'ютерного забезпечення, що виконуються студентами під час лабораторних занять із вищої математики. Якщо заняття в комп’ютерних класах не передбачені планом, можна порекомендувати відвести для них частину аудиторного практичного заняття.

Залежно від теми, що вивчається, ми пропонуємо студентам використовувати для розв'язання задач одну з систем комп'ютерної математики: MatLab, Octave, Mathematica, GeoGebra; інколи зручним для розрахунків виявляється середовище Excel. Навіть студенти, що мають низький рівень підготовки, виявляють зацікавленість і ентузіазм у виконанні завдань на комп'ютері.

Серед студентів, що навчаються англійською мовою, завжди є контингент iз високим рівнем мотивації, 3 одного боку, та просунутими навичками програмування - 3 іншого. Ми пропонуємо цим студентам створення програм, що реалізують алгоритм розв'язку тієї чи тієї задачі, однією з популярних мов програмування (C, Python, Java).

Що стосується діагностики отриманих знань i навичок, у своїй викладацькій практиці автори переважно використовують тестовий формат 
контролю. Тести не потребують великих затрат аудиторного часу, до того ж цей підхід відповідає світовим стандартам.

У ХНЕУ ім. С. Кузнеця, як і в багатьох закладах вищої освіти України, ми використовуємо програмно-інструментальну платформу MOODLE, що дозволяє створювати тести різних типів, проводити та автоматично оцінювати результати тестування студентів. Ми проводимо тестування під час лабораторних занять.

Наведемо фрагмент тестового завдання (із множинним вибором) за темою «Невизначений інтеграл»:

1. When $F(x)$ is the antiderivative of $f(x)$ ?
a) $f^{\prime}(x)=F(x)$
b) $F^{\prime}(x)=f(x)$
c) $f(x)=F(x)+C$
d) $F(x)=-f(x)$

2. Choose the wrong properties of the indefinite integral:
a) $\int d F(x)=F(x)+C$
b) $d\left(\int f(x) d x\right)=f(x)+C$
c) $\int f^{\prime}(x) d x=f(x)+C$
d) $\int f(x) g(x) d x=\int f(x) d x \cdot \int g(x) d x$

3. The integration by parts formula has the form:
a) $\int u d v=u v-\int v d x$
b) $\int u d v=u v+\int v d u$
c) $\int u d v=u v-\int v d u$
d) $\int u d v=u v-\int d u$

4. Choose the integrals that can be found by direct integration.
a) $\int x 2^{x} d x$
b) $\int(x-\pi) d x$
c) $\int\left(x+2^{x}\right) d x$
d) $\int x 2^{x^{2}} d x$

5 . Which of the following integrals can't be found by substitution?
a) $\int \arccos x d x$
b) $\int \cos (4-3 x) d x$
c) $\int x \ln x d x$
d) $\int \frac{\ln x d x}{x}$

6. How to use integration by parts for the integral $\int x^{2} 2^{x} d x$ ?
a) $u=x^{2}, d v=2^{x} d x$
b) $u=x, d v=x 2^{x} d x$
c) $u=2^{x}, d v=x^{2} d x$
d) $u=x 2^{x}, d v=x d x$

7. Choose the integrals that can't be expressed by elementary functions.
a) $\int e^{-x^{2}} d x$
b) $\int e^{-x} d x$
c) $\int x e^{x} d x$
d) $\int \frac{e^{x}}{x} d x$

8. The antiderivative of $f(x)=\sin x$ is
a) $\sin x+C$
b) $-\sin x+C$
c) $\cos x+C$
d) $-\cos x+C$
9. What is $\int \sec ^{2} x d x$ ? 

a) $\frac{1}{3} \sec ^{3} x+C$
b) $\operatorname{tg} x+C$
c) $\operatorname{tg}^{2} x+C$
d) $2 \sec ^{2} x \operatorname{tg} x+C$

10. Calculate by substitution: $\int 5 \sin ^{4} x \cos x d x$
a) $\cos ^{5} x \sin x+C$
b) $\frac{1}{5} \sin ^{5} x+C$
c) $\sin ^{5} x \cos x+C$
d) $\sin ^{5} x+C$

Висновки. Одним із стратегічних напрямків розвитку вищої освіти України є інтеграція в європейський освітній простір. Невід'ємною складовою на цьому шляху $\epsilon$ впровадження англомовного навчання за різними спеціальностями у вітчизняних університетах.

Викладання дисциплін іноземною мовою має багато особливостей i проблем, тому потребує якісного науково-методичного супроводу. Наведені рекомендації щодо організації викладання вищої математики майбутнім спеціалістам галузі інформаційних технологій, згідно 3 досвідом авторів, дозволяють активізувати навчально-пізнавальну діяльність і підвищити іiі ефективність.

Подальші дослідження цієї проблеми можуть бути присвячені пошуку та впровадженню нових навчальних технологій, розробкам у напрямку організації дистанційного англомовного навчання тощо.

\section{СПИСОК ВИКОРИСТАНИХ ДЖЕРЕЛ}

1. Власенко, К. (2018). Про підготовку до викладання математичних дисциплін англійською мовою кафедрою вищої математики ДДМА. Матеріали міжнародної науковометодичної Інтернет-конферениї «Проблеми математичної освіти: виклики сучасності» Взято 3 https://conferences.vntu.edu.ua/index.php/pmovc/pmovc/paper/viewFile/5472/4661

2. Карупу, О. В., Олешко, Т. А., Пахненко, В. В. (2011). Про деякі особливості викладання математичних дисциплін англомовним студентам. Вісник Чернігівського наиіонального педагогічного університету. Серія: Педагогічні науки, 83, 76-79.

3. Карупу, О. В., Олешко, Т. А., Пахненко, В. В. (2012). Деякі особливості викладання математичних дисциплін іноземним студентам. Східно-Свропейський журнал передових технологій, 2/2 (56), 11-14.

4. Карупу, О. В., Олешко, Т. А., Пахненко, В. В. (2018). Про викладання лінійної алгебри та аналітичної геометрії англомовним студентам технічних інститутів НАУ. Фізикоматематична освіта, 4(18), 59-64.

5. Нікулін, О. В., Наконечна, Т. В. (2013). Тримовний математичний міні-словник. Дніпропетровськ, Україна: Біла К. О.

6. Степанян, И. К., Дубинина, Г. А., Ганина, Е. И. (2017). Билингвальный подход к обучению математике иностранных студентов. Международный научно-исследовательский журнал, 12(66), 67-172.

7. Misiura, Ie., Stiepanova, K. (2017). Higher Mathematics. Guidelines to solving practical tasks on the definite integral for Bachelor's (first) degree students of all specialties Simon Kuznets 
Kharkiv National University of $\quad$ Economics. http://www.repository.hneu.edu.ua/jspui/handle/123456789/18126

8. Panova, N., Titarev, V., Toreanik, L. (1995). Integral calculus of functions of one variable: teaching aid for foreign students of all specialties. Kharkiv, Ukraine: Publishing House of KhNUE.

\title{
FEATURES OF TEACHING HIGHER MATHEMATICS IN ENGLISH TO STUDENTS OF COMPUTER SPECIALTIES
}

\author{
Antonina Rybalko \\ Candidate of Physical and Mathematical Sciences, \\ Associate Professor of Higher Mathematics, \\ Economic and Mathematical Methods Department, \\ Simon Kuznets Kharkiv National University of Economics, \\ Kharkiv, Ukraine \\ ORCID ID 0000-0002-2253-1393 \\ antonina.rybalko@hneu.net \\ Kateryna Stiepanova \\ Candidate of Physical and Mathematical Sciences, \\ Associate Professor of Higher Mathematics, \\ Economic and Mathematical Methods Department, \\ Simon Kuznets Kharkiv National University of Economics, \\ Kharkiv, Ukraine \\ ORCID ID 0000-0003-2294-155X \\ stepanova.ekaterina@hneu.net
}

\begin{abstract}
One of the promising directions for the development of education in Ukraine is the introduction of English-language professional training in all program disciplines. Studying in English attracts foreign students who do not speak Ukrainian, and opens up great growth opportunities for Ukrainian students. This article is devoted to the study of problems of teaching higher mathematics in English to students who are not native speakers of English.

Due to the spread of teaching in English, in recent years there has been an increasing number of publications on organizational, methodological and psychological aspects of teaching in multinational groups.

The purpose of the article is to investigate the problems and features of teaching mathematical disciplines to students of computer specialties in English, to present our own pedagogical experience and recommendations for improving the quality of cognitive activity.

Teaching mathematics in English requires defining the format of the classes and careful methodological preparation. The paper presents approaches that allow students to master mathematical terminology. The peculiarities of the creating of methodological support that combines the traditions of national and foreign teaching methodology are considered. In the paper, the attention is paid to the features of mathematical training of future specialists in the field of information technology. The possibilities and advantages of using computer mathematics systems in the study of higher mathematics are highlighted. To diagnose the knowledge gained by students, it is suggested to use tests developed using tools of the Moodle learning platform.

We conclude that the implementation of English-language training is effective in the context of the development of professional competencies of future computer science specialists. The
\end{abstract}

Професіоналізм педагога: теоретичні й методичні аспекти. - Вип. 12. - Слов’янськ, 2020. 


\section{А. РИБАЛКО, К. СТЄПАНОВА}

Особливості викладання вищої математики англійською мовою студентам комп'ютерних спеціальностей

approaches presented, according to the authors' experience, allow to increase the intensity of students' cognitive activity and to improve the quality of acquired knowledge and skills.

Further research on this problem may be devoted to improving the scientific and methodological support, the search of new learning technologies, developments in the organization of distance learning, etc.

Key words: higher education; higher mathematics; teaching in English; multinational groups; computer science students.

\section{REFERENCES}

1. Vlasenko, K. (2018). On preparation for teaching mathematical disciplines in English at the Department of Higher Mathematics of DSMA. Materialy mizhnarodnoi naukovo-metodychnoi Internet-konferentsii «Problemy matematychnoi osvity: vyklyky suchasnosti». Retrieved from https://conferences.vntu.edu.ua/index.php/pmovc/pmovc/paper/viewFile/5472/4661

2. Karupu, O. V., Oleshko, T. A., Pakhnenko, V. V. (2011). About some features of teaching mathematical disciplines to English-speaking students. Visnyk Chernihivskoho natsionalnoho pedahohichnoho universytetu. Seriia: Pedahohichni nauky, 83, 76-79.

3. Karupu, O. V., Oleshko, T. A., Pakhnenko, V. V. (2012). Some features of teaching mathematics to foreign students. Skhidno-Ievropeiskyi zhurnal peredovykh tekhnolohii, 2/2 (56), 1114.

4. Karupu, O. V., Oleshko, T. A., Pakhnenko, V. V. (2018). About teaching linear algebra and analytical geometry to English-speaking students of technical institutes of NAU. Fizykomatematychna osvita, 4(18), 59-64.

5. Nikulin, O. V., Nakonechna, T. V. (2013). Trilingual mathematical mini-vocabulary. Dnipropetrovsk, Ukraine: Bila K. O.

6. Stepanyan, I. K., Dubinina, G. A., Ganina, E. I. (2017). A bilingual approach to teaching mathematics to foreign students. Mezhdunarodnyy nauchno-issledovatelskiy zhurnal, 12(66), 167172.

7. Misiura, Ie., Stiepanova, K. (2017). Higher Mathematics. Guidelines to solving practical tasks on the definite integral for Bachelors (first) degree students of all specialties. Simon Kuznets Kharkiv national university of economics. Retrieved from http://www.repository.hneu.edu.ua/jspui/handle/123456789/18126

8. Panova, N., Titarev, V., Toreanik L. (1995). Integral calculus of functions of one variable: teaching aid for foreign students of all specialties. Kharkiv, Ukraine: Publishing House of KhNUE.

Матеріали надійшли до редакції 12.04.2020 p. 